\title{
MORPHOLOGY AND ANATOMY OF DEVELOPING FRUITS AND SEEDS OF Vismia guianensis (AUBL.) CHOISY (CLUSIACEAE)
}

\author{
MOURÃO, K. S. M. ${ }^{1}$ and BELTRATI, C. M. ${ }^{2}$ \\ ${ }^{1}$ Departamento de Biologia, Universidade Estadual de Maringá, CEP 87020-900, Maringá, Paraná, Brazil \\ ${ }^{2}$ Departamento de Botânica, Instituto de Biociências, Universidade Estadual Paulista, C.P. 199, CEP 13506-900, \\ Rio Claro, São Paulo, Brazil \\ Correspondence to: Káthia Socorro Mathias Mourão, Departamento de Biologia, Universidade Estadual de Maringá, \\ Avenida Colombo, 5790, CEP 87020-900, Maringá, Paraná, Brazil, e-mail: ksmmourao@uem.br \\ Received October 5, 1999 - Accepted February 24, 2000 - Distributed February 28, 2001
}

(With 35 figures)

\begin{abstract}
Morphological, structural and developmental features of fruits and seeds of Vismia guianensis (Aubl.) Choisy. are here presented, with the purpose to elucidate their structure and to contribute to taxonomical and ecological studies of the family. The fruit is a berry and the "rind" is constituted by the exocarp and by the subepidermal layers which constitute the mesocarp. The reddish pulp, rich in starch, is constituted by the parenchymatic mesocarp, with branched secretory ducts and vascular bundles, joined with the endocarp, which arises from a ventral meristem. The bitegmic, anatropous ovules, provided by the endothelium, develop into anatropous, bitegmic and exalbuminous seeds. The reddish uniseriate testa shows phenolic contents. The tegmen becomes crushed resting only the uniseriate exotegmen with undulate, thick walled and lignified cells, which contain a number of calcium oxalate prismatic crystals. The embryo, rich in lipids, is straight and shows foliaceous cotyledons.
\end{abstract}

Key words: Clusiaceae, fruit, seed, Vismia, anatomy.

\section{RESUMO}

Morfologia e anatomia dos frutos e sementes em desenvolvimento de Vismia guianensis (Aubl.) Choisy (Clusiaceae)

Estudaram-se aspectos morfoanatômicos dos frutos e sementes, em desenvolvimento, de Vismia guianensis (Aubl.) Choisy, visando descrevê-los detalhadamente e, desse modo, fornecer subsídios para futuros estudos taxonômicos e ecológicos do grupo. O fruto dessa espécie é uma baga, cuja "casca" é constituída pelo exocarpo e por camadas subepidérmicas que constituem o mesocarpo. O restante do mesocarpo parenquimático, com dutos secretores e feixes vasculares, e o endocarpo, derivado da atividade de um meristema ventral, formam a polpa avermelhada e rica em amido. Os óvulos são anátropos, bitegumentados, com endotélio, e originam sementes também anátropas, bitegumentadas e exalbuminosas. A testa é unisseriada, de coloração avermelhada, com células de conteúdo fenólico. O exotégmen consta inteiramente de esclereídes com paredes anticlinais onduladas, contendo cristais prismáticos de oxalato de cálcio. O restante do tégmen torna-se colapsado. $\mathrm{O}$ embrião reto, rico em material lipídico, apresenta eixo hipocótilo-radicular cilíndrico e cotilédones foliáceos e espessos.

Palavras-chave: Clusiaceae, fruto, semente, Vismia, anatomia. 


\section{INTRODUCTION}

Vismia guianensis (Clusiaceae - Hipericoideae) is a woody species, native of Tropical America that occurs in Colombia, Venezuela, Guyana and in Brazil in the states of Amazonas, Pará, Maranhão, Bahia and Minas Gerais (Reichardt, 1878; Ewan, 1962). It stands out for supplying wood for civil construction, deluxe joinery and carpentry. A gomo-resinous, red-orange juice, resolutive and strongly purgative, also used in the treatment of skin diseases is obtained by incision of the stem bark (Pio Corrêa, 1926).

Engler \& Keller (1925) and Melchior (1964) used fruits and seeds characters, besides the vegetative and floral features, in the delimitation of subfamilies and tribes of Clusiaceae. However, the shortage of detailed ontogenetic studies of fruits and seeds have generated doubts about the relationship and the position of the species in these subfamilies and tribes (Mourão, 1997).

With the same family Clusiaceae, Dionello \& Basta (1980), Basta \& Basta (1984) and Saddi (1988) studied the morphology and anatomy of seeds of Kielmeyera Mart. species (Kielmeyeroideae). The morphology, anatomy and ontogeny of Platonia insignis Mart. (Moronobeoideae) and Mammea americana L. (Calophylloideae) fruits and seeds were studied in details by Mourão \& Beltrati (1995a, b) and Mourão (1997), respectively. However, in Hypericoideae were not found studies of this nature so far.

In view of the exposed, and with the purpose to give continuity to the study of the fruits and seeds of Clusiaceae, in the present work, morphological and anatomical data of the development of the fruits and seeds of Vismia guianensis (Aubl.) Choisy are presented and discussed.

\section{MATERIAL AND METHODS}

The botanical material used in the present work consisted of floral buds, flowers and fruits in different stages of Vismia guianensis (Aubl.) Choisy (Figs. 1-3).

\section{Studied material}

Vismia guianensis (Aubl.) Choisy: Brazil, São Luís, Maranhão, $2^{\circ} 32^{\prime}$ S and $44^{\circ} 17^{\prime} \mathrm{W}$, Forest Reserve of Sacavém (State Park of Bacanga) and near the coastland, col. K. S. M. Mourão 1, I. 1994, flower, fruit, seedling (HRCB 17421); Forest Reserve of Sacavém (State Park of Bacanga), col. K. S. M. Mourão 3, 26. I. 1996, flower, fruit, seedling (HUM 3449); col. K. S. M. Mourão 4, 26. I. 1996, fl., fr. (HUM 3450).

The morphologic characters of the fruits and seeds were described and illustrated, starting from 50 units of fresh material, collected from five individuals. For the fruits and seeds measures (length and diameter) was used a pachymeter, and the fresh weight was obtained using a analytic scale. It was also determined the number of seeds per fruit. For each one of the obtained variables was calculated the arithmetic average and the deviationpattern. The nomenclature to describe the fruits and seeds patterns was based in Radford et al. (1974). The fruit type description was based in Spjut (1994).

Samples of material to morphological and anatomical studies were fixed in F.A.A. $50 \%$ (Johansen, 1940). The conservation of that material was made in Ethanol 70\% (Jensen, 1962). The anatomical description was made starting from the analysis of semi-permanent and permanent slides made with transversal and longitudinal sections of the developing pericarp and seeds.

The slides, the specific tests and the illustrations were made in agreement with methodology described by Mourão \& Beltrati (1995a). It was also used in the preparation of permanent slides, vegetable material embedded in glycol methacrylate according to the technique described by Gerrits (1991).

These slides were stained with Toluidine Blue O (O'Brien et al., 1965) and mounted in Permount. The terminology adopted to define the pericarp layers is in agreement with Roth (1977) and the nomenclature used in the seeds description was that defined for Corner (1976) and modified by Schmid (1986).

\section{RESULTS}

\section{Fruit development}

Vismia guianensis has a superior, pentacarpellary and pentalocular ovary. The ovules are arranged in axile placentation (Figs. 5-7). The outer and inner epidermis is uniseriate, showed cubic cells covered by thin cuticle. 

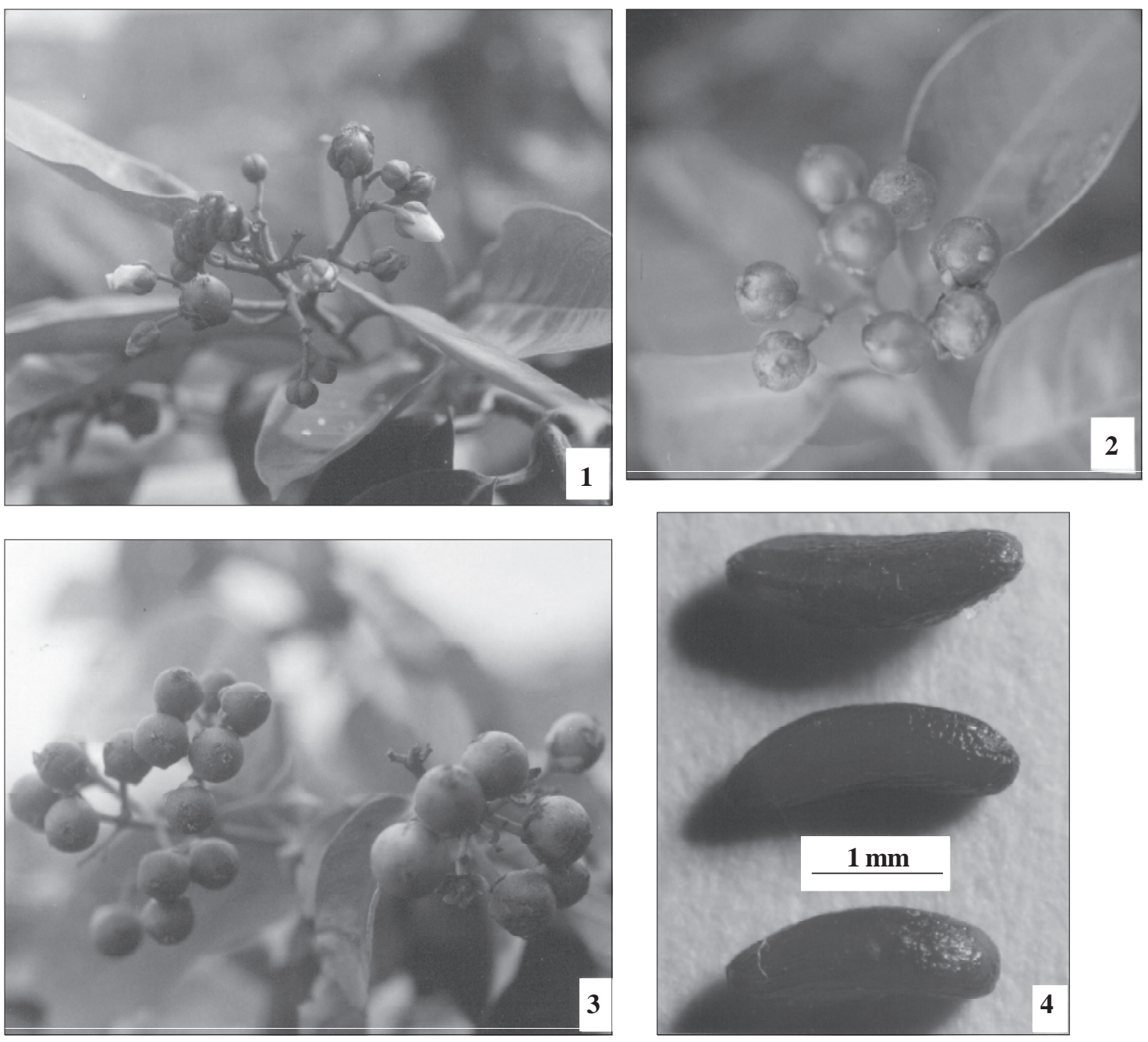

Figs. 1-4 - Vismia guianensis. 1 - Floral buds, flowers and fruits in development. 2 - Immature fruits. 3 - Immature fruits (to the left) and mature fruits (to the right). 4 - Mature seeds in rapheal (above), lateral (to the middle) and antirapheal view (below).

In the outer epidermis was also observed the presence of scattered stomata. The ovarian mesophyll is composed by fundamental parenchyma, with few intercellular spaces, where a number of branched secretory ducts occur (Fig. 14). These ducts can also be observed in the septs (Figs. 6, 7).

In the ovary of floral bud is observed formatting ducts in the mesophyll and in the sept. Apparently, these ducts form schizogenously and develop schizolisigenously (Figs. 18-21). In the young fruit (Fig. 8), the structure of the ovary is basically maintained (Figs. 9, 10) and the cellular divisions occur in all directions, prevailing the periclinals in the subepidermal layers. In the exo- carp, derived from the ovary outer epidermis, scattered lenticels occasionally appear, originated by the activity of a phellogen that produces suberised cells in out direction.

The mesocarp, which derives from the ovarian mesophyll, stays parenchymatic (Fig. 15). The secretory ducts increase in diameter and become branched. The secreted substance is rich in phenolic content and lipids substances. In the endocarp, which derives from the inner epidermis that defines the locule and from the ovary subepidermal layers, an evident region of periclinals divisions can be observed, constituting a ventral meristem (Fig. 15). 

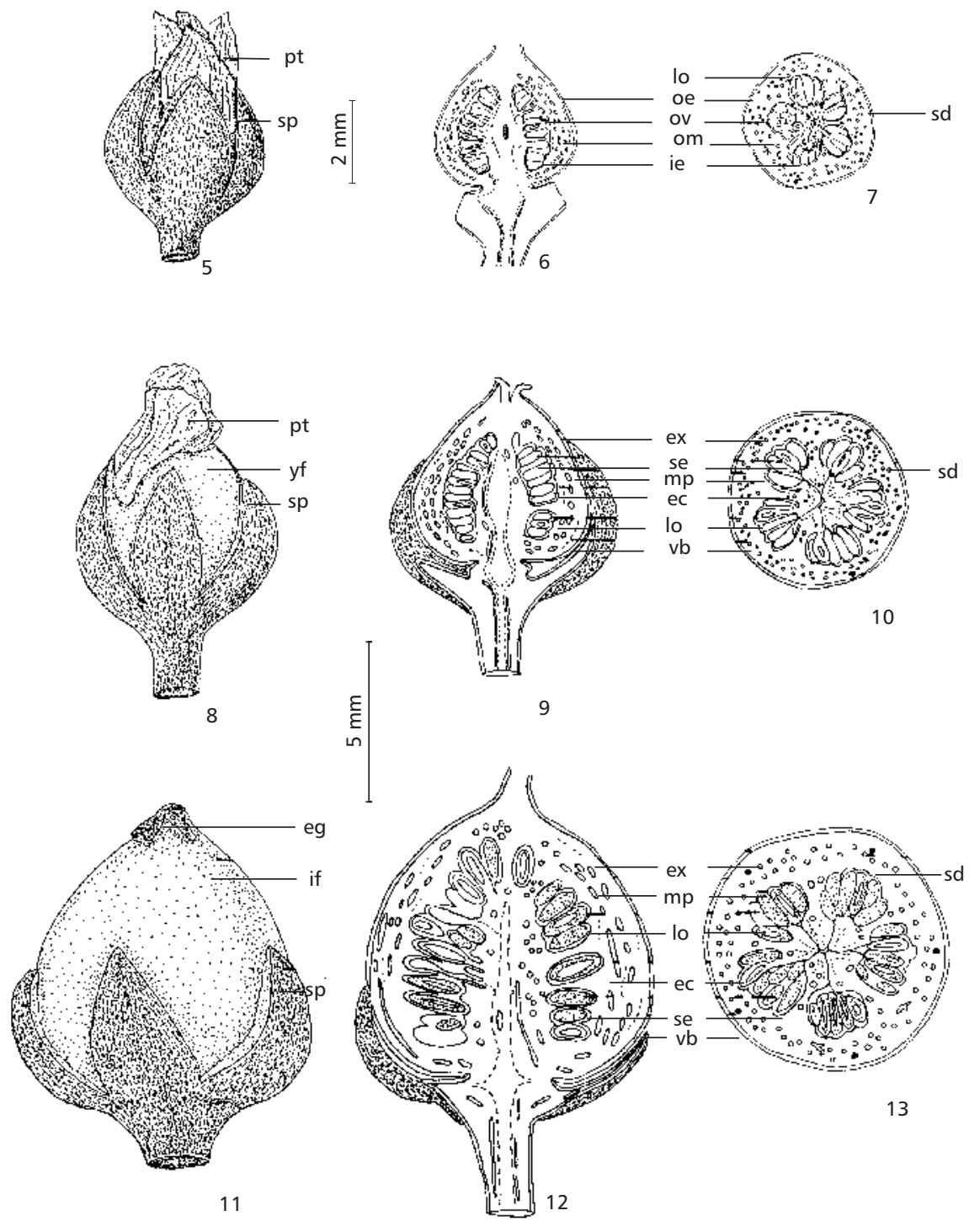

Figs. 5-13 - Vismia guianensis - General aspect, medium longitudinal and transversal sections, respectively, of the fruit development. 5-7 - Flower in anthesis and ovary. 8-10 - Young fruit shortly after fertilization $(0,6 \mathrm{~cm} \times 0,6 \mathrm{~cm}) .11-13-$ Immature fruit $(0,9 \mathrm{~cm}$ x $0,9 \mathrm{~cm})$. (ec - endocarp; eg - stigma; ex - exocarp; if - immature fruit; lo - locule; mp - mesocarp; oe - outer epidermis; om - ovarian mesophyll; ov - ovule; pt - petal; sd - secretory duct; se-seed; vb -vascular bundle; $\mathrm{sp}$ - sepal; yf - young fruit.)

A parenchymatic tissue (Figs. 16, 17) that grows for among the seeds will arise from the meristem.

Most of the ovules will be developed in seeds (Figs. 9, 10, 12, 13), and the immature fruit (Fig. $2,3,11)$ acquires red coloration. The pericarp structure is basically the same of the ovary and of the young fruit (Figs. 12, 13). However, in the endocarp, the complete differentiation of the parenchymatic tissue, that grows of desuniform way for among the seeds can be observed (Fig. 17). 

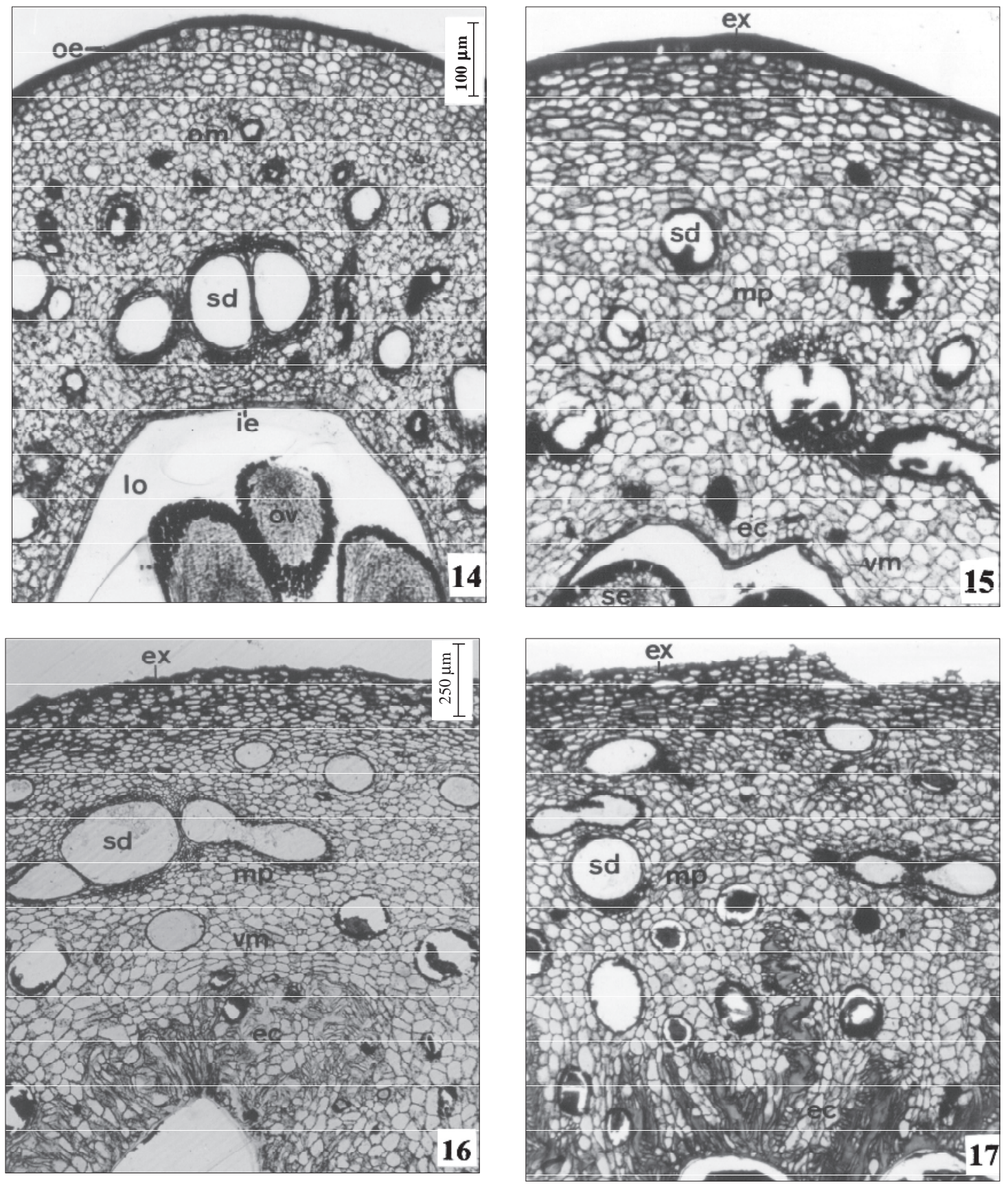

Figs. 14-17 - Vismia guianensis - Detail of the the pericarp development in cross section. 14 - Ovary at the time of fertilization. 15 - Young fruit shortly after fertilization. 16 - Immature fruit $(0.9 \mathrm{~cm} \mathrm{x} 0.9 \mathrm{~cm}) .17-$ Mature fruit $(1.0 \mathrm{~cm} \times 1.0 \mathrm{~cm})$. (ec - endocarp; ex - exocarp; ie - inner epidermis; lo - locule; mp - mesocarp; oe - outer epidermis; om - ovarian mesophyll; ov - ovule; sd - secretory duct; se - seed; vm - ventral meristem.)

The Vismia guianensis fruit is an oblong berry that, in the maturation, when still in plant (Fig. 3 ), has green coloration, passing to a brown co- loration after the maturation. It shows fleshy and mucilaginous pulp, with red coloration and sweetened scent. 

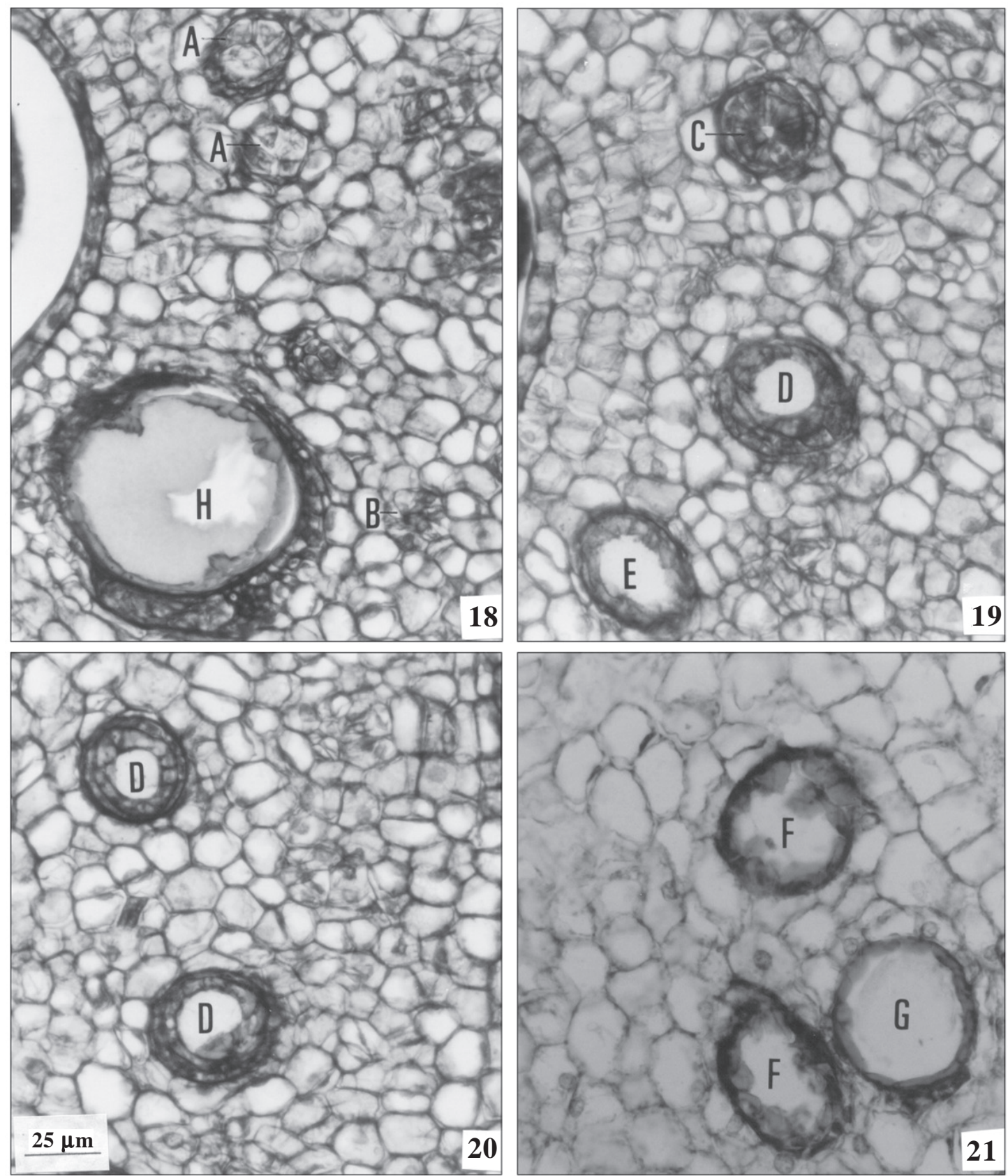

Figs. 18-21 - Vismia guianensis - Secretory ducts in successive phases of differentiation (A to H). 18-20 - Cross-section of the floral bud ovarian mesophyll. 21 - Cross-section of the young fruit mesocarp.

The fruit measures $1.17 \pm 0.17 \mathrm{~cm}$ of length per $1.23 \pm 0.12 \mathrm{~cm}$ of diameter, weighs $1.11 \pm 0.36$ $\mathrm{g}$ (weighed with fresh matter) and shows $177.64 \pm$ 50.72 seeds per fruit.
The "rind" of the mature fruit is formed by the exocarp, derived from the outer epidermis of the ovary, and for several subepidermal layers which constitute the mesocarp, derived from the 
ovarian mesophyll (Figs. 14-17). The mesocarp and endocarp remaining arise the red, translucent pulp, which is rich in starch. In this phase, in the secreted material by the ducts, is not observed the presence of phenolic contents. However, lipids substances can still be observed.

\section{Seed development}

The ovules are anatropous, bitegmic and tenuinucelate (Figs. 22-26). The outer integument is not very developed and shows two cells layers and the inner integument shows six to seven layers.

The outer epidermis of the outer integument shows large cells, approximately cubic, with phenolic contents. The innermost layer of the inner integument shows cells radially elongate, constituting the endothelium. The external, medium (among the two integuments) and the intern cuticle (between the internal integument and the nucellus) can be observed.
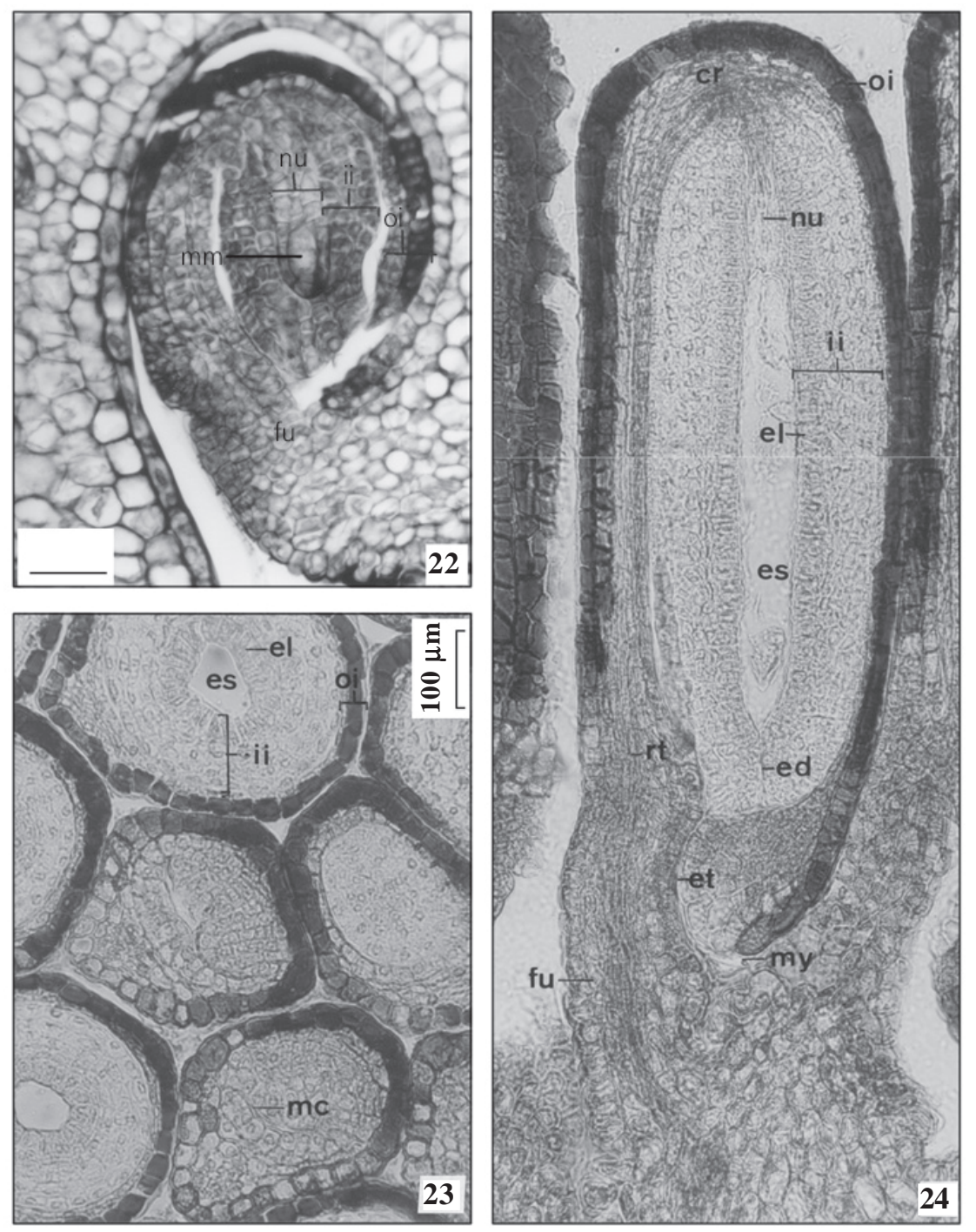

Figs. 22-24 - Vismia guianensis - Ovule. 22 - Longitudinal section of the young ovule. 23-24 - Cross sections and longitudinal section of the fully developed ovules, respectively. (cr - chalazal region; ed - endostome; el - endothelium; es - embryo sac; et - exostome; fu - funicle; ii - inner integument; mc - micropyle chamber; mm - megaspore mother cell; my - micropyle; nu - nucellus; oi - outer integument; om - ovarian mesophyll; rt - rapheal vascular trace.) 
The micropyle channel is formed by the endostome and by the exostome, being these apertures non coincident (zig-zag micropyle).

The embryo sac is longitudinally elongated; a provascular strand goes through the funicle, arriving until the chalaza. The seed structure in the young fruit is basically the same of the ovule. An increase in the size of the cells of the two integuments and the beginning of differentiation of a cells layer with sinuous anticlinals walls in the outer epidermis of the tegmen can be observed (Figs. 27, 28). In the immature seed is observed, besides a beginning of collapse of the tegmen cells, the increase in the undulation and in the thickening of the cells walls of the outer epidermis of this integument. It is observed, also in this phase, some endosperm layers, among the embryo already well developed and the tegmen constituted by large parenchymatic cells with thin walls (Figs. 29, 30).

The mature seeds are red, ellipsoids in shape, elongated, and more or less angular (Fig. 4). The hillun is rounded, the micropyle is obscure and a vascular bundle transverses the raphe, extending until the chalaza. The seed measures $2.38 \pm 0.13$ $\mathrm{mm}$ length per $0.68 \pm 0.04 \mathrm{~mm}$ diameter.

The seed is anatropous and exalbumynous. The whitish-yellow embryo is straight and shows a longer and cylindrical hipocotyl-radicle axis, with two plano-convex cotyledons (Figs. 33-35). It's also rich in lipid material.

In the mature seed the outer epidermis of the testa consists of large, cubic cells, with brown content, due to the presence of the phenolic contents. The other layers of the testa become crushed. The outer epidermis of the tegmen is entirely constituted of sclereids which contains a number of prismatic crystals of calcium oxalate (Figs. 31, 32). Its lignified anticlinals walls have sinuous aspect in superficial view. The other layers of the tegmen become crushed (Fig. 33). Some endospermic layers can still be observed between the embryo and the tegmen, increasing in number in direction to the chalazal end.

\section{DISCUSSION}

The occurrence of secretory structures as ducts in the pericarp of Vismia guianensis was also described in another species of the Clusiaceae family (Corner, 1976; Mourão \& Beltrati, 1995a; Mourão, 1997).
In $V$. guianensis the exocarp derives from the ovary outer epidermis. This feature has also been described in Platonia insignis (Moronobeoideae) by Mourão \& Beltrati (1995a). In Mammea americana, however, the exocarp originates from the outer epidermis and from the first subepidermical layer of the ovarian mesophyll, that originates the periderm (Mourão, 1997).

From the histogenetical point of view, Garcin apud Roth (1977) recognizes endocarp types which originate directly from the existing parenchyma and endocarp formations which develop from a special meristem. This special meristem may originate exclusively from the inner epidermis, from subepidermal layers only, or from a mixture of both. Roth (1977) designated this special meristem of ventral or adaxial meristem, which adds new cell layers to the pericap, can be located either in the inner epidermis or in subepidermal layers. This meristem has been received this denomination due to the entire carpel symmetry.

In the fruit development of $V$. guianensis as in Mammea americana (Mourão, 1997), the growth and the fruit final form of $V$. guianensis are due to the cellular divisions that occur in all directions and, also, to the activity of a ventral meristem that arises the endocarp.

In a recent fruit classification purposed by Barroso et al. (1999) the fruit of Vismia species is included in the "bacóide - campomanesoideo" type. This fruit type according to these authors presents a fleshy pericarp and its central cavity is occupied by an uniform pulp tissue where the locules can still be distinguished, containing each usually few seeds. However, in the fruit of $V$. guianensis the activity of a ventral meristem arises a parenchymatic tissue that grows among the seeds and in this case, it would assemble more with those defined by the authors as "bacóide - bacídio" type, where the locules are not evident in the mature fruit.

The anatomical characteristics of the $V$. guianensis pericarp (Hypericoideae - Vismeae) resembles those described by Green (1884) for two species of Hypericum (Hypericoideae - Hypericeae).

The ovule structure of $V$. guianensis resembles that of Hypericum patulum and H. mysorense, described by Rao (1957) and those of all the species of Hypericaceae described by Corner (1976). 

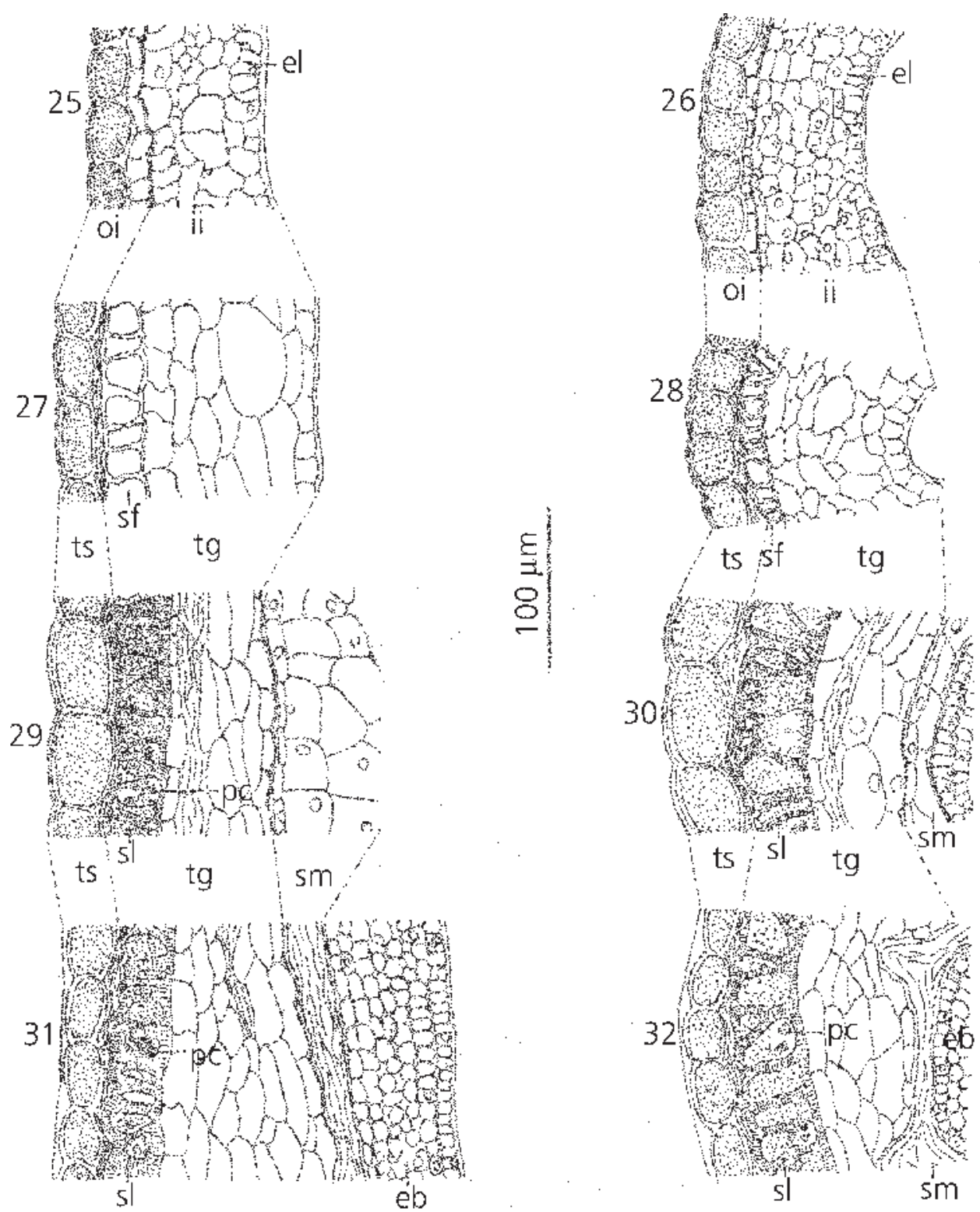

Figs. 25-32 - Vismia guianensis - Longitudinal and cross sections of the developing seed-coat, respectively. 25-26 - Ovule. 27-28 - Young seed. 29-30 - Immature seed. 31-32 - Mature seed. (eb - embryo; el - endothelium; ii - inner integument; oi - outer integument; pc - prismatic crystals; sf - sclereid layer in differentiation; sl - sclereid layer; sm - endosperm; $\operatorname{tg}$ - tegmen; ts - testa.)

The presence of the endothelium in the ovule of $V$. guianensis was also mentioned by Rao (1957) in Hypericum patulum and H. mysorense, by Corner (1976) in Clusia (Clusioideae - Clusieae) and by Mourão \& Beltrati (1995a) in Platonia insignis.
In Hypericoideae, Crété (1936), Rao (1957) and Corner (1976) mentioned the occurrence of epidermal cells in the testa with brown tannic content and lignified exotegmen. However, according to Rao (1957), in H. patulum (Hypericeae) the endotesta would be the sclerotic layer. 

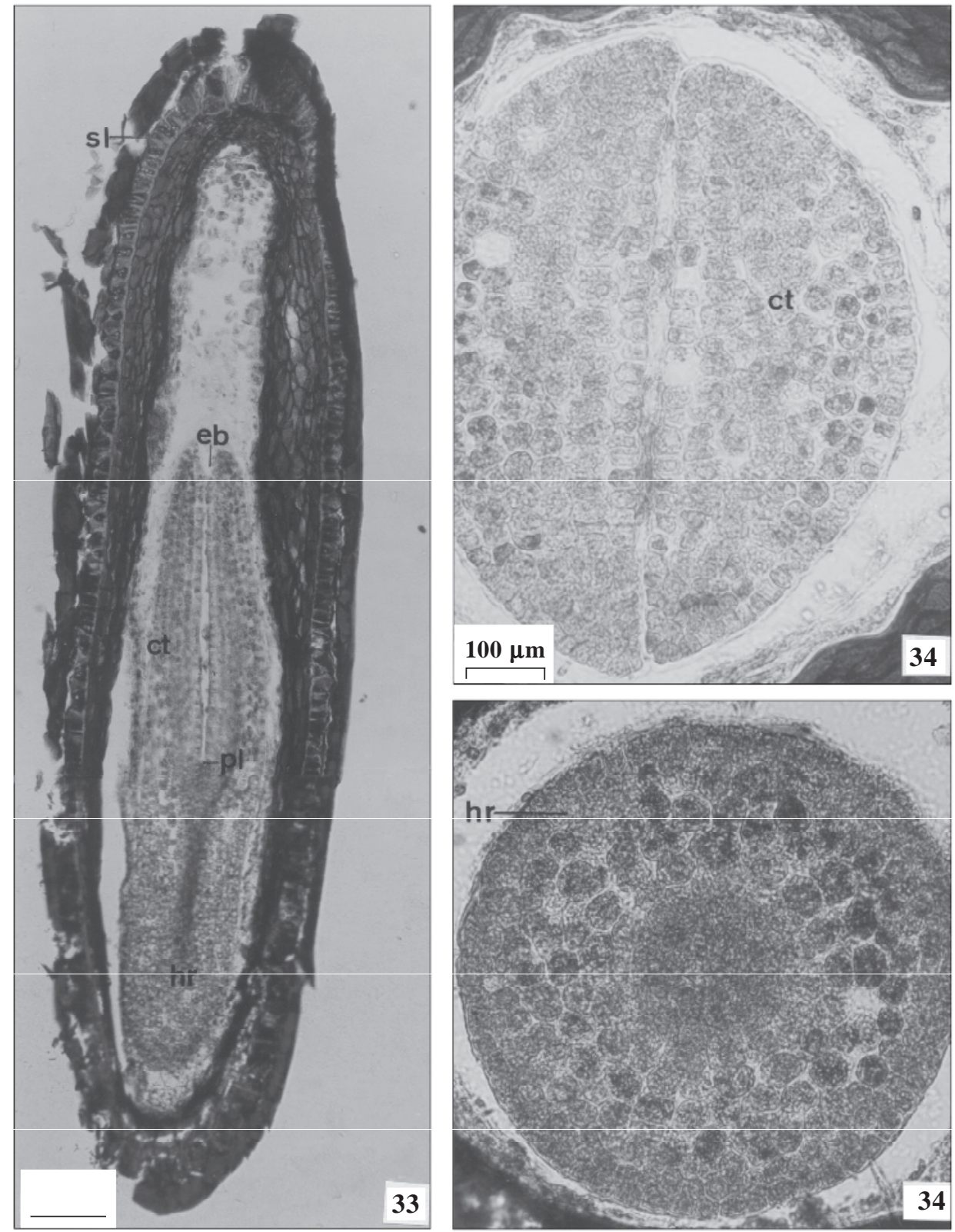

Figs. 33-35 - Vismia guianensis - Mature seed. 33 - Longitudinal section showing tegmen outer epidermis constituted entirely by sclereids and the embryo. 34-35 - Cross-sections showing the thick, plano-convex cotyledons and hipocotyl radicle axis. (sl - sclereid layer; ct - cotyledon; eb - embryo; hr - hipocotyl-radicle axis; pl - plumule.)

In $V$. guianensis was observed that the exotegmen is lignified, unlike mentioned by Corner (1976) that studied a not identified species of Vismia.

Corner (1976) affirmed that the characteristic layer of thick-walled stellate in the exotegmen of
Hypericaceae, also occurs in the tribe Clusieae (Clusiaceae - Clusioideae), in Elatinaceae and Geraniaceae.

In the embryo classification purpose by Brandza (1908) and Guillaumin (1910) to Guttiferae and Hypericaceae species, the embryo of V. guia- 
nensis resembles those species of Hypericaceae and it is similar to the found in the tribe Clusieae Guttiferae (embryo of the type I). According to Martin (1946) embryo classification, the embryo of $V$. guianensis occupies more than half of the seminal cavity. It is axial, spatulate and transverseoblong.

The occurrence of lipids substances in seeds of species of the family Clusiaceae is widely registered in the literature (Brandza, 1908; Earle \& Jones, 1962; Vaughan, 1970; Basta \& Basta, 1984; Bentes et al., 1986/87; Adeyeye, 1991; Mourão \& Beltrati, 1995b). In the present study it was verified that the main reservation substance that occurs in the embryo of $V$. guianensis is of lipids nature.

Acknowledgments - Are due to CAPES for financial support. Thanks are also due to Profa. Dra. Cássia Mônica Sakuragui (Universidade Estadual de Maringá, PR) for correcting the English.

\section{REFERENCES}

ADEYEYE, A., 1991, Studies on seed oils of Garcinia kola and Calophyllum inophyllum. J. Sci. Food Agric., 57: 441-442.

BARroso, G. M., MORIM, M. P., PEIXOTO, A. L. \& ICHASO, C. L. F., 1999, Frutos e sementes, morfologia aplicada à sistemática de dicotiledôneas. Editora UFV, Viçosa, 443p.

BASTA, S. B. D. \& BASTA, F., 1984, Estudos morfológicos das sementes e do desenvolvimento das plântulas de Kielmeyera coriacea Mart. Brasil Florestal, 58: 25-30.

BENTES, M. H. S., SERRUYA, H., ROCHA FILHO, G. N., GODOY, R. L. O., CABRAL, J. A. S. \& MAIA, J. G. S., 1986/87, Estudo químico das sementes de bacuri. Acta Amazonica, 16/17 (n. único): 363-368.

BRANDZA, G., 1908, Recherches anatomiques sur la germination des Hypéricacées et des Guttifères. Annales des Science Naturelles Bot., série 9(8): 221-300.

CORNER, E. J. H., 1976, Clusiaceae, pp. 97-103 (1 ${ }^{\text {st }}$ vol.), pp. 92-111 ( $2^{\text {nd }}$ vol.). In: E. J. H. Corner, The seeds of dicotyledons. University Press, Cambridge.

CRÉTÉ, P., 1936, Transformation de l'ovule en graine chez l'Androsaemum officinale All. Bull. Bot. Soc. France, 83: 654-657.

DIONELLO, S. B. \& BASTA, F., 1980, Informações sobre os caracteres quantitativos e qualitativos dos frutos e sementes de Kielmeyera coriacea Mart. Brasil Florestal, 44: 75-84.

EARLE, F. R. \& JONES, Q., 1962, Analyses of seed samples from 113 plant families. Economic Botany, 16: 221-250.
ENGLER, A. \& KELLER, R., 1925, Guttiferae, pp. 154-237 (21 ${ }^{\text {st }}$ vol.). In: A. Engler \& K. Prantl, Die naturlichen Pflanzenfamilien. Verlag Wilhelm Engelmann, Leipzig, $2^{\text {nd }}$ ed.

EWAN, J., 1962, Synopsis of the south american species of Vismia (Guttiferae). Bull. of the Unit. States Nat. Mus., 35: 293-373.

GREEN, J. R., 1884, On the organs of secretion in the Hypericaceae. Journ. of the Linn. Soc. of London, 20: 451464.

GUILLAUMIN, A., 1910, L'étude des germinations appliquée à la classification des genres et a la phylogénie des groupes. Rev. Gén. de Bot., 22: 449-468.

GERRITS, P. O., 1991, The application of glycol methacrylate in histotechnology; some fundamental principles. Department of Anatomy and Embriology, Gröningen, Netherlands.

JENSEN, W. A., 1962, Botanical histochemistry: principles and pratice. W. H. Feeman, San Francisco, 408p.

JOHANSEN, D. A., 1940, Plant microtechnique. McGrawHill Book, New York, 523p.

MARTIN, A. C., 1946, The comparative internal morphology of seeds. The Amer. Midl. Natur, 36(3): 513-660.

MELCHIOR, H., 1964, Guttiferae (Clusiaceae) pp. 170-173 (v.II). In: A. Engler, Syllabus de Planzenfamilien. Gebruder Borntraeger, Berlin, Nikolassu.

MOURÃO, K. S. M. \& BELTRATI, C. M., 1995a, Morfologia dos frutos, sementes e plântulas de Platonia insignis Mart. (Clusiaceae). I. Aspectos anatômicos dos frutos e sementes em desenvolvimento. Acta Amazônica, 25(1/2): 11-32.

MOURÃO, K. S. M. \& BELTRATI, C. M., 1995b, Morfologia dos frutos, sementes e plântulas de Platonia insignis Mart. (Clusiaceae). II. Morfo-anatomia dos frutos e sementes maduros. Acta Amazônica, 25(1/2): 33-46.

MOURÃO, K. S. M., 1997, Morfologia e desenvolvimento dos frutos, sementes e plântulas de Vismia guianensis (Aubl.) Choisy e Mammea americana L. (Clusiaceae Lindley). Tese de Doutorado, Unesp, Rio Claro, SP, 156p.

O'BRIEN, T. P., FEDER, N. \& Mc CULLY, M. E., 1965, Polychromatic staining of plant cell walls by toluidine blue O. Protoplasma, 59: 368-373.

PIO CORRÊA, M., 1926, Dicionário das plantas úteis do Brasil e das exóticas cultivadas. Ministério da Agricultura, Rio de Janeiro, 1ํvol., 500.

RADFORD, A. E., DICKINSON, W. C., MASSEY, J. R. \& BELL, C. R., 1974, Vascular plant systematics, Harper \& Row Publishers, New York, 891p.

RAO, A. N., 1957, The embriology of Hypericum patulum Thunb. and H. mysorense Heyne. Phytomorphology, 7: 36-45.

REICHARDT, H. G., 1878, Hypericaceae, pp. 181-212, t. 33-39. In: C. F. P. Martius, von., Flora Brasiliensis, vol. XII, pars. I (fasc. LXXXI). 
ROTH, I., 1977, Fruits of Angiosperms, 10 ${ }^{\text {th }}$ vol., 666p. In: Encyclopedia of plant anatomy. Gebruder Borntreger, Berlin.

SADDI, N., 1988, Micromorphological evidence in the genus Kielmeyera Martius (Guttiferae). Rev. Brasil. Biol., 48(4): 697-720.

SCHMID, R., 1986, On cornerian and other terminology of agiospermous and gymnospermous seed coats: historical perspective and terminological recommendations. Taxon, 35(3): 476-491.
SPJUT, R. W., 1994, A systematic treatment of fruit types. Memo. of the New York Bot. Gard., 70: 1-82.

VAUGHAN, J. G., 1970, The structure and utilization of oil seeds. Chapman and Hall Ltda., London, 279p. 